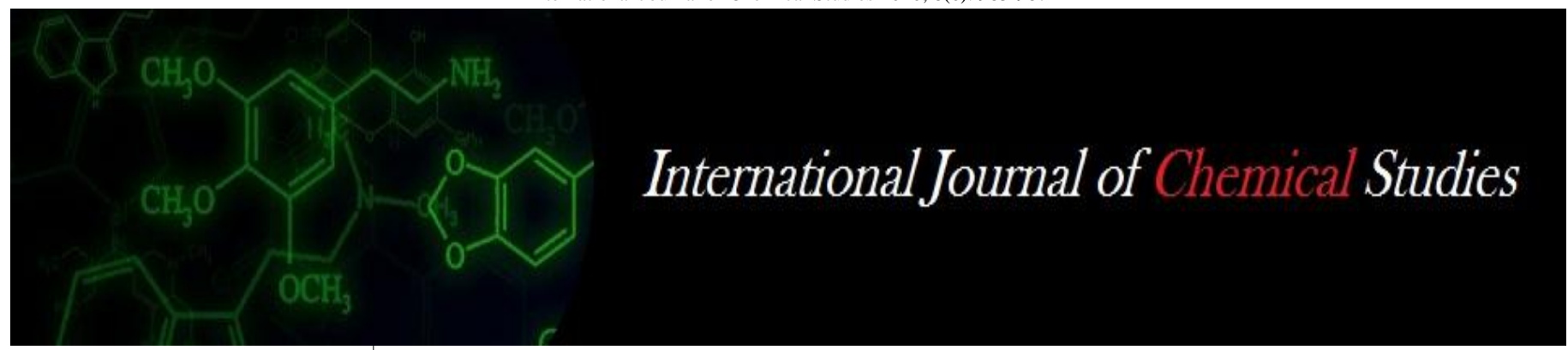

P-ISSN: 2349-8528

E-ISSN: 2321-4902

www.chemijournal.com

IJCS 2020; 8(6): 983-987

(C) 2020 IJCS

Received: 13-09-2020

Accepted: 25-10-2020

\section{Payel Pal}

Department of Agricultural Chemistry and Soil Science, Bidhan Chandra Krishi

Viswavidyalaya, Mohanpur, West Bengal, India

\section{Nyape Bam}

Department of Agricultural Chemistry and Soil Science, Bidhan Chandra Krishi

Viswavidyalaya, Mohanpur, West Bengal, India

\section{Joy Dutta}

Department of Agricultural Chemistry and Soil Science, Bidhan Chandra Krishi Viswavidyalaya, Mohanpur, West Bengal, India

\section{SK Patra}

Department of Agricultural Chemistry and Soil Science, Bidhan Chandra Krishi Viswavidyalaya, Mohanpur, West Bengal, India
Corresponding Author: Payel Pal

Department of Agricultural Chemistry and Soil Science, Bidhan Chandra Krishi Viswavidyalaya, Mohanpur, West Bengal, India

\section{Techno-economic evaluation of gravity fed drip irrigation and nitrogen nutrition on gladiolus in Gangetic alluvial plains of eastern India}

\author{
Payel Pal, Nyape Bam, Joy Dutta and SK Patra
}

DOI: https://doi.org/10.22271/chemi.2020.v8.i6n.10894

\begin{abstract}
Optimization of water and nitrogen is vital for gladiolus production. Field experiments were carried out during rabi seasons of 2012-13, 2013-2014 and 2014-15 to evaluate the four irrigation regimes (gravityfed drip irrigation schedule at $0.6,0.8$ and 1.0 of pan evaporation replenishment, $\mathrm{E}_{0}$ including surface irrigation as control) and three settings of nitrogen nutrition (100\% RDN as vermicompost, 50\% RDN as vermicompost $+50 \%$ RDN as fertilizer and $100 \% \mathrm{RDN}$ as fertilizer) on gladiolus cv. American beauty. The results showed that under assured irrigation water supply, maximum spike and corm yields, gross return, net return and BCR (3.44) was obtained with optimal drip irrigation at $1.0 \mathrm{E}_{0}$ with $50 \% \mathrm{RDN}$ as vermicompost $+50 \%$ RDN as fertilizer. However, under limited irrigation water supply, moderate deficit drip irrigation at $0.8 \mathrm{E}_{0}$ with $50 \% \mathrm{RDN}$ as vermicompost $+50 \% \mathrm{RDN}$ as fertilizer was found most viable alternative in deriving higher yields, gross return, net return and BCR (3.32). Under water scarce, reasonable good yields, gross return, net return and BCR (2.62) was accomplished with higher deficit drip irrigation at $0.6 \mathrm{E}_{0}$ with $50 \% \mathrm{RDN}$ as vermicompost $+50 \% \mathrm{RDN}$ as fertilizer. The findings highlight the techno-economic feasibility of low-cost gravity drip irrigation and nitrogen management for efficient utilization of available groundwater and nitrogen resources for profitable gladiolus cultivation in Gangetic alluvial plains of eastern India.
\end{abstract}

Keywords: Gladiolus, gravity drip irrigation, spikes, corms, crop water use, economics

\section{Introduction}

Gladiolus (Gladiolus hybridus Hort.) commonly known as flag flower or sword lily is an important herbaceous ornamental bulbous plant grown extensively in sub-humid tropical and sub-tropical climate. The popularity of the flower plant is widespread in many countries of the world for its aesthetic, social and economic values. This funnel shaped cut flower has high demand in both domestic and international markets for its short duration, magnificent and attractive inflorescence with florets of dazzling colors, huge forms and varying sizes (Kumari et al. 2014) ${ }^{[10]}$. It is largely used in artistic garlands, floral ornaments, bouquets and interior decorations and possesses excellent keeping quality and can withstand long distance transportation (Meena et al. 2018) ${ }^{[13]}$.

The major gladiolus producing states in India are Karnataka, Maharashtra, Assam, Tamil Nadu, Andhra Pradesh, Kerala, Uttar Pradesh, Madhya Pradesh, Chhattisgarh, Odisha, Uttarakhand and West Bengal. In India, it covers 11,800 ha area and produces 42,150 MT of loose flower and 13.26 million numbers of cut flower (NHB 2018) ${ }^{[14]}$.

The soil water availability is an important environmental factor which has prominent influences on the growth, flower yield and quality of gladiolus. The excess or short supply of water during any physiological stages of plant has adverse effects on flower productivity and quality (Pereira et al. 2009) ${ }^{[16]}$. Frequent but precise quantity of irrigation water application matching with plant water requirement is the key for sustainable flower production (Rathore and Singh 2009, Deshmukh 2012) ${ }^{[18,5]}$. Under limited water supply, irrigation scheduling is considered a critical component to ensure favourable soil water regime in the crop root zone for increasing the quantity and quality of the produce with higher water use efficiency (Panigrahi et al. 2011) ${ }^{[15]}$. Deficit irrigation is the modern approach of irrigation management strategy to solve the issues of precarious water resources with minimal yield compromisation (Pereira et al. 2002) ${ }^{[17]}$. 
Optimum irrigation schedule and appropriate quantity of water applied at the right time are the deciding factors on increased yield and quality of flowers (Begum et al. 2007, ElNaggar and Byari 2009) ${ }^{[2,6]}$. Drip irrigation is an advanced water saving technology because it maintains optimum soil water balance to meet the daily needs of water for plant and renders higher water use efficiency as result of the direct application of accurate amounts of water in the vicinity of root zone (Brahma et al. 2010, Abd El-Wahed and Ali 2013) $[3,1]$. It is superior to other methods of irrigation because it maintains a uniform distribution of water and nutrients around the rhizosphere and reduces runoff, soil evaporation and deep percolation loss which favoured increased flower yield (Deshmukh and Hardaha 2014) ${ }^{[4]}$.

Nitrogen is most crucial plant nutrition factor for stimulating growth, flower yield and quality of gladiolus (Leghri et al. 2011) [11]. High levels of NPK fertilizers in a balanced proportion result in high flower yield, quality and corm and cormel production (Yadav et al. 2020) [22]. Ironically, prolonged use of fertilizer nitrogen has adverse effect on the environment as regards to soil health deterioration, groundwater contamination, human health hazards and substantial yield reduction (Maurya and Beniwal 2003) ${ }^{[12]}$. In this perspective, the integrated use of nitrogen through organic manure and inorganic chemical fertilizer is the alternative for restoring soil and crop productivity (Singh and Pandey 2006) ${ }^{[20]}$. The vermicompost is an excellent sources of slow releasing nutrients which sustains yield and improves the physical, chemical and biological properties of soil (Singh et al. 2014, Kumar et al. 2019) ${ }^{[19,10]}$.

In the Gangetic alluvial plains of eastern India, gladiolus is a promising and cash rewarding flower plant and has a huge market demand all the year round. Although the cost of cultivation of gladiolus is more expensive than the major competing flower crops, however the profit margin is very high. Paradoxically, the local resource poor farmers grow the crop following the conventional furrow method of irrigation, which is quite inefficient and renders substantial loss of water and nutrients in deep percolation resulting into low water and nutrient use efficiencies, sub-optimal yield and inferior flower quality. The problem is acute in sandy loam soils, where downward leaching of water and nutrients is more pronounced. In addition, the plant often suffers from water scarcity during some parts of their growth cycle. Since gladiolus cultivation in this region is gaining popularity, but the technical and economical aspects of the drip irrigation and nitrogen nutrition is rather scanty. Keeping all the issues in view, the present study was undertaken with the objectives of optimizing water requirement by gravity-fed drip irrigation schedule coupling with nitrogen management for maximum flower production and monetary benefit from gladiolus.

\section{Materials and Methods}

\subsection{Description of study area}

The field experiments were carried out during three successive rabi seasons of 2012-13, 2013-2014 and 2014-15 at Regional Research Station, Gayeshpur, Nadia, Bidhan Chandra Krishi Viswavidyalaya. The area belongs to the Gangetic alluvial plains of eastern India. The experimental site is lying at $22^{\circ} 58^{\prime} 31^{\prime \prime} \mathrm{N}$ latitude and $88^{\circ} 26^{\prime} 20^{\prime \prime} \mathrm{E}$ longitude with an altitude of $9.75 \mathrm{~m}$ above AMSL. The climate is humid sub-tropics. Mean monthly temperature varies between 37.6 ${ }^{0} \mathrm{C}$ and $25.4{ }^{\circ} \mathrm{C}$ in summer and $23.7{ }^{\circ} \mathrm{C}$ and $10.5{ }^{\circ} \mathrm{C}$ in winter. Mean annual rainfall is $1500 \mathrm{~mm}$ and three-fourth of it being received during four monsoon months from June through
September. Pan evaporation varies from 1.1 to $4.9 \mathrm{~mm} \mathrm{day}^{-1}$. Soil is sandy loam in texture (Typic Fluvaquept) with $35.25 \%$ clay having bulk density $1.49 \mathrm{Mg} \mathrm{m}^{-3}$, organic C $5.6 \mathrm{~g} \mathrm{~kg}^{-1}$, $\mathrm{pH} 6.9$, EC $0.25 \mathrm{dS} \mathrm{m}^{-1}$ with low in available $\mathrm{N}(168.7 .1 \mathrm{~kg}$ $\left.\mathrm{ha}^{-1}\right)$ and medium in available $\mathrm{P}\left(35.6 \mathrm{~kg} \mathrm{ha}^{-1}\right)$ and available $\mathrm{K}$ $\left(151.5 \mathrm{~kg} \mathrm{ha}^{-1}\right)$. Soil has hydraulic conductivity of $22.8 \mathrm{~mm}$ $\mathrm{hr}^{-1}$, field capacity of $52.37 \%$ and permanent wilting point of $15.64 \%$.

\subsection{Experimental treatments and design layout}

The field experiment comprised of twelve treatment combinations with four irrigation regimes (gravity drip irrigation schedule at $0.6,0.8$ and 1.0 of pan evaporation replenishment, $\mathrm{E}_{0}$ including surface irrigation as control) assigned in the main plots and three settings of nitrogen nutrition $(100 \%$ recommended dose of nitrogen (RDN) as organic vermicompost, $50 \%$ RDN as organic vermicompost + $50 \% \mathrm{RDN}$ as inorganic fertilizer and $100 \% \mathrm{RDN}$ as inorganic fertilizer) in sub-plots was laid out in a split plot design with three replications.

\subsection{Agronomic manipulations}

The unsprouted, healthy and disease free medium sized corms ( $5 \mathrm{~cm}$ diameter) of gladiolus $\mathrm{cv}$. American beauty were planted during second week of November in each experimental year at 6-7 cm depth with crop geometry of 30 $\mathrm{cm}$ row to row and $25 \mathrm{~cm}$ plant to plant distance. The unit plot size was $3.0 \mathrm{~m} \times 1.0 \mathrm{~m}$ leaving aside $0.5 \mathrm{~m}$ bund width and $1.0 \mathrm{~m}$ irrigation channel. The number of corms planted per unit plot was 40 . The corms prior to planting were treated with $0.2 \%$ carbendazim for half an hour. The desired amount of vermicompost used as a source of organic nitrogen containing $2.5 \% \mathrm{~N}, 1.48 \% \mathrm{P}$, and $1.20 \% \mathrm{~K}$ was applied in the selected plots as per adopted schedules during the final land preparation and was thoroughly mixed up with the soil. The recommended dose of inorganic fertilizer nitrogen used for the flower plant was $100 \mathrm{~kg} \mathrm{~N}$ per hectare in the form of urea. All plots received a common dose of $60 \mathrm{~kg} \mathrm{P}_{2} \mathrm{O}_{5}$ and $60 \mathrm{~kg}$ $\mathrm{K}_{2} \mathrm{O}$ per hectare as single superphosphate and muriate of potash, respectively. One-third dose of prescribed $\mathrm{N}$ and full doses of $\mathrm{P}_{2} \mathrm{O}_{5}$ and $\mathrm{K}_{2} \mathrm{O}$ were applied as basal at the time of planting and the remaining two-third dose of $\mathrm{N}$ was topdressed in two equal splits at 30 and 60 days after planting. Five representative plants from the inner rows of each replicated plot were randomly selected for recording spike and corm yields at harvest in each year. The flower spikes were harvested 5-6 times in third week of January and continued up to first week of February in the next year. Standard cultural practices and plant protection measures were equally performed in all the treatments for better growth and development of the plants.

\subsection{Irrigation schedules}

Irrigation water was applied as per proposed schedules. The farmers' practice of conventional surface irrigation at $30 \mathrm{~mm}$ depth was applied at an interval of 19-20 days in furrows. In gravity-fed drip irrigation system, irrigation was imposed in the schedule of 1.0, 0.8 and 0.6 of pan evaporation replenishment $\left(\mathrm{E}_{0}\right)$ at 3 days interval. Lateral drip lines of 12 $\mathrm{mm}$ diameter were placed in between two rows. Two drippers per plant with discharge rate of $1.8 \mathrm{lph}$ per dripper operating at a pressure of $0.65 \mathrm{~kg} \mathrm{~cm}^{-2}$ were provided on opposite side of each plant at a distance of $30 \mathrm{~cm}$. In all four number of irrigation was applied in surface irrigation while 23 number of irrigation was given for gravity-fed drip irrigation system. In 
drip irrigation, deep tubewell water was lifted to a $500 \mathrm{~L}$ capacity over head tank commissioned in a platform at a height of $3.3 \mathrm{~m}$ above the ground level. The water used for surface irrigation was measured with Parshall flume. The depth of irrigation water applied for surface irrigation was $120 \mathrm{~mm}$ and for drip irrigation scheduling of 1.0, 0.8 and 0.6 of $\mathrm{E}_{0}$ was $95.3,76.1$ and $57.1 \mathrm{~mm}$, respectively.

\subsection{Economic analysis}

Benefit-cost ratio (BCR) analysis was carried out to assess the techno-economic feasibility of gravity-fed drip irrigation visà-vis surface irrigation coupling with different nitrogen nutrition on gladiolus. The seasonal cost of gravity drip irrigation system with $4 \mathrm{HP}$ water pump included $4 \%$ depreciation, $10 \%$ interest rate and $2 \%$ for repair and maintenance calculated from the fixed cost. The life span of the gravity-fed drip system was considered to be 10 years. The cost of production accommodated the expenses incurred on field preparation, planting, intercultural operation, harvesting and processing of the produce, cost of corms, mineral fertilizers and vermicompost, crop protection measures and irrigation charges including their application cost. The gross return was worked out by accounting the prevailing average market price of the spikes and corms produced during the experimental period. The net return was estimated by deducting the total cost of production from the gross return. The benefit-cost ratio (BCR) of each treatment was calculated by dividing the net return with the respective cost of cultivation.

\subsection{Statistical analysis}

The average yield data of three years obtained for spike and corms yields were subjected to analysis of variance techniques using software packages of MS Excel and SPSS 16.0 version. Statistical significance between means of individual treatments was assessed using Fisher's least significant difference (LSD) at 5\% level of probability (Gomez and Gomez 1984) ${ }^{[7]}$.

\section{Results and Discussion}

\subsection{Spike and corm yield}

The overall spike and corm yields of gladiolus were significantly differed by the interaction effects between irrigation regime and nitrogen nutrition (Table 2). The results in general indicated that irrespective of nitrogen nutrition, increasing deficit water regimes by drip irrigation system progressively decreased both the spikes and corms yields. Likewise, regardless of levels and methods of irrigation imposed, combined application of both inorganic and organic sources of nitrogen at 50:50 proportion displayed highest yields in comparison with $100 \%$ nitrogen in individual form. However, maximum yield of spikes (243000 spikes ha-1) as well as corms (360000 corms ha has $^{-1}$ watained with optimum drip irrigation schedule at $1.0 \mathrm{E}_{0}$ coupling with $50 \%$ RDN as vermicompost $+50 \% \mathrm{RDN}$ as fertilizer $\left(\mathrm{I}_{2} \mathrm{~N}_{2}\right)$. This treatment combination was statistically identical with moderate deficit drip irrigation schedule at $0.8 \quad \mathrm{E}_{0}$ supplemented with 50\% RDN as vermicompost + 50\% RDN as fertilizer $\left(\mathrm{I}_{3} \mathrm{~N}_{2}\right)$ with the corresponding values of 235000 spikes ha ${ }^{-1}$ and 353333 corms ha ${ }^{-1}$, respectively. Significantly the lowest average yields of spikes (209667 spikes ha-1) and corms (265333 corms ha-1) was recorded with higher deficit drip irrigation schedule at $0.6 \quad \mathrm{E}_{0}$ with $50 \% \mathrm{RDN}$ as vermicompost $+50 \% \mathrm{RDN}$ as fertilizer $\left(\mathrm{I}_{4} \mathrm{~N}_{2}\right)$. Conventional surface irrigation provided either single or in combination with organic and inorganic form of nitrogen demonstrated moderate yields ranging from 182000 to $211333 \mathrm{ha}^{-1}$ for spikes and 213333 to $280000 \mathrm{ha}^{-1}$ for corms. Maximum yield of spikes and corms due to optimal or marginal deficit irrigation by gravity drip irrigation system in association with the integration of inorganic and organic form of nitrogen was probably due to sustenance of favourable soil water regimes and more availability of soil and applied nitrogen in the rhizosphere which altogether might have facilitated more absorption of water and nutrients through proliferated root system resulting into increased plant growth and yield (Islam et al. 1990, Tiwari et al. 2003, Begum et al. 2007, Rathore and Singh 2009) ${ }^{[8,21,2,18]}$. The marked reduction in spike and corm yield in higher level of deficit drip irrigation regime irrespective of nitrogen nutrition was ascribed to acute soil water stress which might have failed to fulfill the water requirement of the plant and consequently resulted in lower spike and corm yields (Begum et al 2007) ${ }^{[2]}$. Water saving is an important criteria where substantial amount of water could saved by adopting controlled drip irrigation system at flexible schedules which could be brought for irrigating the unirrigated land for gladiolus cultivation. In this study, the water saving at various levels of drip irrigation varied from 20.6 to $52.4 \%$ as compared with conventional surface irrigation. The amount of water saving was found more in deficit irrigation regime than in optimum irrigation regime.

\subsection{Economic analysis}

The detailed total cost of production incurred cost for irrigation, fertilizers and organic vermicompost including all agronomic inputs along with the gross monetary returns, net monetary returns and benefit-cost ratio (BCR) under different treatment combinations of gravity drip and surface irrigation schedules in combination with variable nitrogen nutrition on gladiolus is furnished in Tables 1 and 2. A perusal of data showed that cost of cultivation for different treatments gradually increased with increase in irrigation water level and addition of vermicompost manure. The cost of cultivation for drip irrigation schedules and surface irrigation accompanying with different nitrogen nutrition through organic and inorganic substrates was almost identical. In each irrigation regime, incorporation of vermicompost substantially increased the cost of production (Table 1). The gross return, net return and BCR increased progressively with the proportionate increase in spike and corm yields absolutely due to increase in drip irrigation level supplemented with vermicompost manuring, whereas the corresponding values were intermediate in surface irrigation complemented with different nitrogen nutrition. Maximum gross return ( $\left.\square 1935000 \mathrm{ha}^{-1}\right)$, net return ( $\left.\square 1499135 \mathrm{ha}^{-1}\right)$ and BCR (3.44) were obtained with optimum level of drip irrigation schedule at $1.0 \mathrm{E}_{0}$ along with $50 \% \mathrm{RDN}$ as vermicompost $+50 \% \mathrm{RDN}$ as fertilizer $\left(\mathrm{I}_{2} \mathrm{~N}_{2}\right)$ which were immediately followed by moderate level of deficit drip irrigation schedule at $0.8 \mathrm{E}_{0}$ coupling with $50 \% \mathrm{RDN}$ as vermicompost $+50 \% \mathrm{RDN}$ as fertilizer $\left(\mathrm{I}_{3} \mathrm{~N}_{2}\right)$ with the corresponding value of $\square 1881667$ $\mathrm{ha}^{-1}, \square 1445889 \mathrm{ha}^{-1}$ and 3.32 , respectively. Reasonably moderate gross return $\left(\square 1579000 \mathrm{ha}^{-1}\right)$, net return $(\square 1143307$ $\mathrm{ha}^{-1}$ ) and BCR (2.62) were found with higher level of deficit drip irrigation schedule at $0.6 \quad \mathrm{E}_{0}$ with $50 \% \mathrm{RDN}$ as vermicompost $+50 \% \mathrm{RDN}$ as fertilizer $\left(\mathrm{I}_{4} \mathrm{~N}_{2}\right)$. The latter two treatment combinations are likely to be beneficial under limited to scarce irrigation water available condition. On the contrary, conventional surface irrigation complemented with $50 \% \mathrm{RDN}$ as vermicompost $+50 \% \mathrm{RDN}$ as fertilizer $\left(\mathrm{I}_{1} \mathrm{~N}_{2}\right)$ 
showed relatively modest effect as compared with $\mathrm{I}_{4} \mathrm{~N}_{2}$ with the value of gross return $\left(\square 1616667 \mathrm{ha}^{-1}\right)$, net return ( $\square 1184036 \mathrm{ha}^{-1}$ ) and BCR (2.74). The higher monetary returns and $\mathrm{BCR}$ in optimal $\left(1.0 \mathrm{E}_{0}\right)$ or slightly deficit irrigation level $\left(0.8 \mathrm{E}_{0}\right)$ by drip irrigation system provided with the integration of organic and inorganic form of nitrogen at 50:50 proportion could be the attributed to the sustenance of favourable soil water regime and available nitrogen in the vicinity of root zone across the growth stages, thereby promoting higher root elongation and proliferation, more absorption of water and nutrients which eventually increased the higher yield of spike and corm of gladiolus plant.

Table 1: Details of cost calculation for drip and surface irrigations, nitrogen nutrition and agronomic inputs for gladiolus cultivation

\begin{tabular}{|c|c|c|c|c|c|c|c|c|c|}
\hline Treatment & $\begin{array}{l}\text { Depth of } \\
\text { water } \\
\text { applied } \\
(\mathrm{cm})\end{array}$ & $\begin{array}{c}\text { Total } \\
\text { volume of } \\
\text { water }(\mathrm{L})\end{array}$ & $\begin{array}{c}\text { Pump } \\
\text { operation } \\
\text { (h) }\end{array}$ & $\begin{array}{c}\text { Diesel } \\
\text { consumption } \\
\text { (L) }\end{array}$ & $\begin{array}{c}\text { Cost of } \\
\text { irrigation } \\
\text { including } \\
\text { application } \\
\left(\square \text { ha }^{-1}\right)\end{array}$ & $\begin{array}{c}\text { Cost of fertilizers, } \\
\text { vermicompost } \\
\text { including application } \\
\left(\square \mathbf{h a}^{-1}\right)\end{array}$ & $\begin{array}{c}\text { System } \\
\text { cost } \\
\text { incurred } \\
\left(\square \mathbf{h a}^{-1}\right)\end{array}$ & $\begin{array}{c}\text { General cost } \\
\text { of } \\
\text { cultivation } \\
\left(\square \text { ha }^{-1}\right)\end{array}$ & $\begin{array}{c}\text { Total cost of } \\
\text { cultivation ( } \square \\
\left.\text { ha }^{-1}\right)\end{array}$ \\
\hline $\mathrm{I}_{1} \mathrm{~N}_{1}$ & 14.00 & 1400000 & 25.93 & 12.96 & 1583 & 21923 & 3500 & 412500 & 439506 \\
\hline $\mathrm{I}_{1} \mathrm{~N}_{2}$ & 14.00 & 1400000 & 25.93 & 12.96 & 1583 & 15048 & 3500 & 412500 & 432631 \\
\hline $\mathrm{I}_{1} \mathrm{~N}_{3}$ & 14.00 & 1400000 & 25.93 & 12.96 & 1583 & 7747 & 3500 & 412500 & 425330 \\
\hline $\mathrm{I}_{2} \mathrm{~N}_{1}$ & 11.64 & 1164000 & 21.56 & 10.78 & 1917 & 21923 & 6400 & 412500 & 442740 \\
\hline $\mathrm{I}_{2} \mathrm{~N}_{2}$ & 11.64 & 1164000 & 21.56 & 10.78 & 1917 & 15048 & 6400 & 412500 & 435865 \\
\hline $\mathrm{I}_{2} \mathrm{~N}_{3}$ & 11.64 & 1164000 & 21.56 & 10.78 & 1917 & 7747 & 6400 & 412500 & 428564 \\
\hline $\mathrm{I}_{3} \mathrm{~N}_{1}$ & 9.68 & 968000 & 17.93 & 8.96 & 1830 & 21923 & 6400 & 412500 & 442653 \\
\hline $\mathrm{I}_{3} \mathrm{~N}_{2}$ & 9.68 & 968000 & 17.93 & 8.96 & 1830 & 15048 & 6400 & 412500 & 435778 \\
\hline $\mathrm{I}_{3} \mathrm{~N}_{3}$ & 9.68 & 968000 & 17.93 & 8.96 & 1830 & 7747 & 6400 & 412500 & 428477 \\
\hline $\mathrm{I}_{4} \mathrm{~N}_{1}$ & 7.76 & 776000 & 14.37 & 7.19 & 1745 & 21923 & 6400 & 412500 & 442568 \\
\hline $\mathrm{I}_{4} \mathrm{~N}_{2}$ & 7.76 & 776000 & 14.37 & 7.19 & 1745 & 15048 & 6400 & 412500 & 435693 \\
\hline $\mathrm{I}_{4} \mathrm{~N}_{3}$ & 7.76 & 776000 & 14.37 & 7.19 & 1745 & 7747 & 6400 & 412500 & 428392 \\
\hline
\end{tabular}

$\mathrm{I}_{1}$ : conventional surface irrigation at $30 \mathrm{~mm}$ depth, I2: drip irrigation at $1.0 \mathrm{Eo}$, I3: drip irrigation at 0.8 Eo, I4: drip irrigation at 0.6 Eo; $\mathrm{N}_{1}: 100 \%$ RDN as organic vermicompost, $\mathrm{N}_{2}: 50 \%$ RDN as organic vermicompost $+50 \%$ RDN as inorganic fertilizer, $\mathrm{N}_{3}: 100 \%$ RDN as inorganic fertilizer; **Diesel consumption @ 0.5 lph with discharge rate of 15 lps; ***Cost of diesel @ $\square 48 \mathrm{~L}^{-1}$; Assumed efficiency of surface irrigation $65 \%$ and gravity fed drip irrigation $85 \%$

Table 2: Economics of gladiolus cultivation under drip and surface irrigations and nitrogen nutrition (average data of 3 years)

\begin{tabular}{|c|c|c|c|c|c|c|c|c|}
\hline Treatment & $\begin{array}{c}\text { Spikes yield } \\
\left(\text { no. of spikes ha }{ }^{-1}\right)\end{array}$ & \begin{tabular}{|c|}
$\begin{array}{c}\text { Corms yield } \\
(\text { no. of corms ha }\end{array}$ \\
\end{tabular} & $\begin{array}{c}\text { Price of spikes } \\
\left(\square \mathbf{h a}^{-1}\right)\end{array}$ & \begin{tabular}{|c|}
$\begin{array}{c}\text { Price of corms } \\
\left(\square \mathbf{h a}^{-1}\right)\end{array}$ \\
\end{tabular} & \begin{tabular}{|c|}
$\begin{array}{c}\text { Gross return } \\
\left(\square \mathbf{h a}^{-1}\right)\end{array}$ \\
\end{tabular} & $\begin{array}{c}\text { Total cost of } \\
\text { cultivation }\left(\square \mathrm{ha}^{-1}\right) \\
\end{array}$ & \begin{tabular}{|c|} 
Net return \\
$\left(\square\right.$ ha $\left.^{-1}\right)$
\end{tabular} & \begin{tabular}{|l|} 
Benefit- \\
cost ratio
\end{tabular} \\
\hline $\mathrm{I}_{1} \mathrm{~N}_{1}$ & 182000 & 213333 & 910000 & 426667 & 1336667 & 439506 & 897161 & 2.04 \\
\hline $\mathrm{I}_{1} \mathrm{~N}_{2}$ & 211333 & 280000 & 1056667 & 560000 & 1616667 & 432631 & 1184036 & 2.74 \\
\hline $\mathrm{I}_{1} \mathrm{~N}_{3}$ & 200667 & 266667 & 1003333 & 533333 & 1536667 & 425330 & 1111337 & 2.61 \\
\hline $\mathrm{I}_{2} \mathrm{~N}_{1}$ & 227667 & 280000 & 1138333 & 560000 & 1698333 & 442740 & 1255593 & 2.84 \\
\hline $\mathrm{I}_{2} \mathrm{~N}_{2}$ & 243000 & 360000 & 1215000 & 720000 & 1935000 & 435865 & 1499135 & 3.44 \\
\hline $\mathrm{I}_{2} \mathrm{~N}_{3}$ & 232667 & 346667 & 1163333 & 693333 & 1856667 & 428564 & 1428103 & 3.33 \\
\hline $\mathrm{I}_{3} \mathrm{~N}_{1}$ & 217000 & 276000 & 1085000 & 552000 & 1637000 & 442653 & 1194347 & 2.70 \\
\hline $\mathrm{I}_{3} \mathrm{~N}_{2}$ & 235000 & 353333 & 1175000 & 706667 & 1881667 & 435778 & 1445889 & 3.32 \\
\hline $\mathrm{I}_{3} \mathrm{~N}_{3}$ & 227333 & 344000 & 1136667 & 6888000 & 1824667 & 428477 & 1396190 & 3.26 \\
\hline $\mathrm{I}_{4} \mathrm{~N}_{1}$ & 181667 & 210667 & 908333 & 421333 & 1329667 & 442568 & 887099 & 2.00 \\
\hline $\mathrm{I}_{4} \mathrm{~N}_{2}$ & 209667 & 265333 & 1048333 & 530667 & 1579000 & 435693 & 1143307 & 2.62 \\
\hline $\mathrm{I}_{4} \mathrm{~N}_{3}$ & 199000 & 250667 & 995000 & 501333 & 1496333 & 428392 & 1067941 & 2.49 \\
\hline SEm \pm & 2600 & 2813 & - & - & - & - & - & - \\
\hline $\mathrm{CD}(0.05)$ & 8433 & 8867 & - & - & - & - & - & - \\
\hline
\end{tabular}

$\mathrm{I}_{1}$ : conventional surface irrigation at $30 \mathrm{~mm}$ depth, $\mathrm{I}_{2}$ : drip irrigation at $1.0 \mathrm{Eo}, \mathrm{I}_{3}$ : drip irrigation at 0.8 Eo, $\mathrm{I}_{4}$ : drip irrigation at $0.6 \mathrm{Eo} ; \mathrm{N}_{1}: 100 \%$ RDN as organic vermicompost, $\mathrm{N}_{2}: 50 \% \mathrm{RDN}$ as organic vermicompost $+50 \% \mathrm{RDN}$ as inorganic, $\mathrm{N}_{3}: 100 \%$ RDN as inorganic; Cost of spike @ $\square 5.0$ and corm@ $\square 2.0$ per piece

\section{Conclusion}

Based on the results of the study, it can be concluded that under assured irrigation water supply, maximum spike and corm yields, highest gross return, net return and BCR was obtained with imposition of optimal drip irrigation schedule at $1.0 \mathrm{E}_{0}$ coupling with $50 \% \mathrm{RDN}$ as vermicompost $+50 \% \mathrm{RDN}$ as fertilizer. However, under limited irrigation water supply, moderate deficit drip irrigation schedule at $0.8 \mathrm{E}_{0}$ with $50 \%$ RDN as vermicompost $+50 \%$ RDN as fertilizer was the most viable alternative in achieving relatively higher spike and corm yields, gross return, net return and BCR. Under water scarce, reasonable yields, gross return, net return and BCR was accomplished with higher deficit drip irrigation schedule at $0.6 \mathrm{E}_{0}$ with $50 \% \mathrm{RDN}$ as vermicompost $+50 \% \mathrm{RDN}$ as fertilizer. This study attempted to portray the technoeconomic feasibility of precise planning and efficient management of available groundwater resources by adopting low cost gravity-fed drip irrigation system and integrated nitrogen management which is useful for the gladiolus growers of the Gangetic alluvial plains of eastern India. This also serves in choosing the best practical option of irrigationnitrogen coupling for gladiolus according to the availability of resources and socio-economic conditions of the farmers.

\section{References}

1. Abd El-Wahed MH, Ali EA. Effects of irrigation system, amounts of irrigation water and mulching on corn yield, water use efficiency and net profit. Agricultural Water Management 2013;120(31):64-71.

2. Begum RA, Rahman MN, Mondol ATMAI, Rahman MJ, Khan FN. Effect of different moisture regimes on the 
growth and quality of gladiolus. International Journal of Sustainable Crop Production 2007;2(5):43-45.

3. Brahma S, Phookan DB, Kachari M, Hazarika TK, Das K. Growth, yield and economics of broccoli under different levels of nitrogen fertigation. Indian Journal of Horticulture 2010;67:279-282.

4. Deshmukh G, Hardaha MK. Effects of irrigation and fertigation scheduling under drip irrigation in papaya. Journal of AgriSearch 2014;1(4):216-220.

5. Deshmukh MR. Effect of various irrigation methods on growth, flowering and yield of tuberose (Polyanthes tuberosa L.). Journal of Horticultural Sciences 2012;7(1):94-97.

6. El Naggar AI, Byari SH. Effects of Irrigation frequency regimes and weed control management on field grown tuberoses (Polianthes Tuberosa, L.) in the Saudi Arabian western region: 2 . Bulb and bulblet's yield, growth and development and grade qualities. Egyptian Journal of Horticulture 2009;36(1):119-147.

7. Gomez KA, Gomez AA. Statistical procedure for agricultural research, $2^{\text {nd }}$ Edition, International Rice Research Institute, John Wiley and Sons, New York 1984, 1-340.

8. Islam T, Sarkar H, Alam J. Water use and yield relationships of irrigated potato. Agricultural Water Management 1990;18:173-179.

9. Kumar V, Mehra B, Daniel S, Jan N. Effect of organic manures and irrigation schedule on growth and yield of Sarpagandha under teak based Agroforestry system. The Pharma Innovation Journal 2019;8(6):86-88.

10. Kumari RV, Kumar DP, Arunkumar B, Mahadevamma M. Effect of integrated nutrient management on floral and cormal parameters in gladiolus (Gladiolus hybridus Hort.). International Journal of Agriculture Science 2014;10(1):15-22.

11. Lehri SM, Kurd AA, Rind MA, Bangulza NA. The response of Gladiolus tristis L. to $\mathrm{N}$ and $\mathrm{P}_{2} \mathrm{O}_{5}$ fertilizers. Sarhad Journal of Agriculture 2011;27(2):185-188.

12. Maurya PR, Beniwal SV. Use of biofertilizers in horticultural crops. Newsletter Agrobios 2003;I(11):1213.

13. Meena MK, Byadwal RK, Meena MK, Sharma AK, Rathore JP. Impact of integrated nutrient management on vegetative growth and flowering quality of gladiolus (Gladiolus hybridus Hort.) cv. American Beauty. Archives of Agriculture and Environmental Science 2018;3(3):310-316.

14. NHB. Area and production statistics of horticultural crops. New Delhi: National Horticulture Board 2018.

15. Panigrahi $\mathrm{P}$, Sahu NN, Pradhan S. Evaluating partial root-zone irrigation and mulching in okra (Abelmoschus esculentus L.) under a sub-humid tropical climate. Journal of Agriculture and Rural Development in the Tropics and Subtropics 2011;112(2):169-175.

16. Pereira JRD, Carvalho JA, Paiva PDO, Silva DJS, Souza AMG, Souza KJ, et al. Crescimento e produção de hastes florais de gladíolo cultivado sob diferentes tensões de água no solo. Ciência e Agrotecnologia 2009;33(4):965970.

17. Pereira LS, Oweis T, Zairi A. Irrigation management under water scarcity. Agricultural Water Management 2002;57(3):175-206.

18. Rathore AC, Singh JN. Optimization of nitrogen application and irrigation for improved growth and spike production of tuberose (Polianthes tuberosa L.). Indian Journal of Soil Conservation 2009;37(1):45-49.

19. Singh R, Kumar M, Raj S, Kumar S. Effect of integrated nutrient management (INM) on growth and flowering in gladiolus (Gladiolus grandiflorus L.) cv. White prosperity. Annals of Horticulture 2014;6(2):251-258.

20. Singh V, Pandey M. Effect of integrated nutrient management on yield of and nutrient uptake by onion and on soil fertility. Journal of the Indian Society of Soil Science 2006;54:365-367.

21. Tiwari KN, Singh A, Mal PK. Effect of drip irrigation on yield of cabbage (Brassica oleracea L. var. capitata) under mulch and non-mulch conditions. Agricultural Water Management 2003;58:19-28.

22. Yadav U, Agrawal N, Katre P, Tamrakar SK, Tripathi MP. Effect of irrigation and fertigation on gladiolus crop water requirement, yield and water use efficiency in Chhattisgarh plain. International Journal of Current Microbiology and Applied Sciences 2020;9(6):29132923. 